\title{
Language In Pakistani Crime Reporting: Use Of Gender Specific Adjectives
}

\author{
Sarwet Rasul \\ \& \\ Sidra Irshad \\ Fatima Jinnah Women University, Rawalpindi
}

\begin{abstract}
Newspapers use language as a tool to create power structures based on gender; and it is through specific vocabulary that they present men and women as different stereotypes in the society. Through language choices not only men and women are presented as different but also as unequal: the former is powerful while the later is powerless, the former is independent while the later is dependant. The present paper attempts to analyze news reporting in the Pakistani print media with special focus on the relationship between gender and language used in crime report headings. It is examined how gender specific adjectives are used to create the reality of women as weak, subdued, and submissive; while men are projected as empowered, dominant and authoritative. Out of the selected four newspapers two are English (Dawn and The News) while two are Urdu (Jang and Khabrain). From these newspapers the headings of crime reports that project the relationship between gender and choice of adjectives, have been sorted out and analyzed under two categories: category ' $A$ ' deals with adjectives used for men while category ' $\mathrm{B}$ ' deals with adjectives used for women.
\end{abstract}

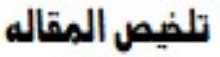

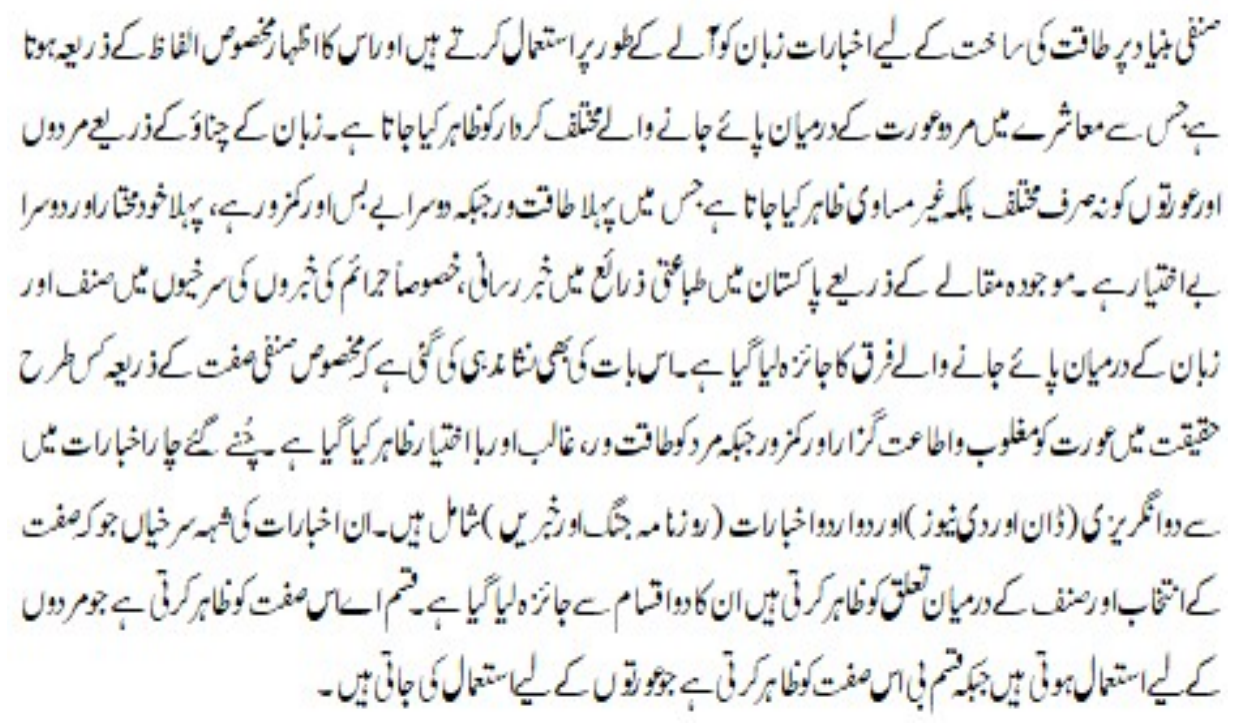




\section{Issue in the Context of Pakistani Society}

In the traditional patriarchal society of Pakistan gender ideologies and differentiations in terms of male supremacy and female subordination are formed in all the walks of life. Like most of the fields, Pakistani media works under a structure in which women are insecure sufferers and passive victims. This media projection is in fact a reproduction of the existing and established image of women in our society. In general in the Pakistani society a prejudice against women exists in all the spheres of life; thus Pakistani news papers, both English and Urdu, also give a biased and prejudiced coverage to women in crime reporting. This prejudice and bias is created through gender specific vocabulary as well as language structures.

\section{Aim of the Research}

The aim of the research is to high-light how Pakistani newspapers use language, particularly adjectives, in crime reporting as a tool to project women as dependant and weak stereotypes in opposition to dominant and powerful men; and how biased reporting reinforces the stereotypes in the society.

\section{Significance of the Research}

Since media is a reflector of the sociological makeup of a society, the deconstruction of language used for crime reporting can significantly contribute to the understanding of gender framework operating in the society. In the Pakistani context, this paper will bring forward the existing image of women in the society, and the role of media in portraying this biased image. Hence, it will generate further interest in the subject for further studies in the area. It is also expected that in the general broader context of place of women in the Pakistani society, it will add to the awareness of general public/readers regarding the image of women in media.

\section{Literature Review}

\section{Gender: Defining the Term}

'Gender' refers to the sum total of the social and cultural characteristics of one sex, be it male or female. Wharton (2005: 6) citing Kessler and Mekenna (1978) says that gender is 'psychological, social and cultural aspects of maleness and femaleness'. Sex, on the other hand, is only a biological factor which is defined by Wharton as, 'distinguishable characteristics, which include chromosomal differences, external and internal sexual structures, hormonal productions and other psychological differences, and secondary sex characteristics' (2005:7). 
Frank and Triechler (1989:10) also cite Virginia (1986) in defining the differences of sex and gender. sex is a fundamental biological characteristic that exist even in bacteria ... there are two sexes: one which makes egg-females, and one which makes sperm (pollen) -males'. While gender is 'a cultural phenomenon, and culture in turn is the accumulation of information and behavior patterns that are passed on from generation and which holds societies together'.

Social structure defines gender and its categories in a way different than sex such as wife a woman, dentist a man, and so on (Oakley,1972). Oakley further argues that gender is a visible sum of the qualities including mannerism, way of speaking, dress, and choice of topics in conversation and so on. To Cornell (2004), in its initial meaning, the term gender was used critically in the social, political and scientific works, however, it introduced the new dimensions of the human history as for the first time it looked forward to see women's subjugation in different spheres of life and how women can play much positive roles in the social, political and economic life.

As gender cannot be treated as an individual quality or the characteristics as the people belonging to a particular area exhibit the same behavioral traits as the majority of those locality posses on the basis of their approach to a particular sex category. So on the basis of these ideas gender can rightly be treated as a 'multi level phenomenon', which enables the individuals to work on the social interactions and institutions to work under the category of gender (Warton: 2005).

\section{Gender Ideologies in Different Societies}

A cursory glance at the human history shows that gender ideologies and ideas about females' inferiority existed everywhere in the course of time. However, since 1951 the term gender has been increasingly used to distinguish a social role or a gender role and personal identity that are different from the biological sex (Nirajana, 2004). He argues, 'Gender has always been a part of societal realities everywhere' (136). To Cornell (2004) gender discrimination in the American society was produced through centuries, but the particular idea got its background regarding its realization from legal inequality and gradually spread to other walks of life.

The Indian society is patriarchal and a woman is expected to worship her husband, irrespective of the character of the husband himself (Mohanty, 2004). In the same way Chinese practice of binding the feet of female infants to make them attractive in the eyes of the male members of the society is a sign of gender discrimination; and despite all the progress in China, is still practiced in the inner rural areas. 


\section{Role of Media in Promoting Gender Ideologies: Pakistani Media}

To Jasam (2001) media is a channel of promoting ideas and reinforcing ideologies. Burki (2004) asserts that media plays an important role in shaping our perception of the terms male or female. It not only reflects but also creates and reshapes the public opinion. To her the drive to promote gender sensitization and a gendered perspective to news, events and entertainment in the media includes both the sexes, where men and women are slotted into particular roles and are expected to stick to certain codes of conduct.

Dagar (2004) discusses the coverage of beauty contests and models as a reflection of the image of women created by media. This is not limited to India rather is a universal phenomenon in the world of media and to Ahmar (2004) its reason lies in the fact that men design and define media policies, priorities and agenda, including how women are portrayed and presented. Tassaro (2002) asserts in this regard that overall media is a profit seeking industry, and stereotypes are the general and extensive perceptions irrespective of the fact whether they are right or wrong, which are exploited by media to gain profit.

In the case of Pakistan, media plays a vital role in reinforcing the image and position of women in the social fabric. In Pakistani media generally women are under represented, and dehumanizing language is used for them. Pakistani newspapers use sensational and gender biased language to project women as feeble, inferior and incapable.

\section{Language and Media}

'Language like all other social institutions and value systems, does not serve all its speakers equally' (Frank and Treichler, 1989:15). Refering to the role of language in determining the patterns of hirearchy in terms of gender, Mayor and Pugh (1987) point out the marked difference in linguistic choices for the two sexes in which bieng 'Miss' or 'Mrs.' is more exceptional than bieng a simple 'Mr' . The common pronoun is 'he' and not 'she' when gender is unknown. To Coates (1998:377) overall the language of women in terms of social structure is a 'powerless language'. Refering to the same characteristic of language Hasan (2001) claims that adjectives used for boys/men explicitly or implicitly have the connotations of being active, creative, energetic, wild and angry where as girls/women are projected as submissive, delicate, beautiful and dependent.

As far as the use of language in media to create gender identities is concerned, media is a reflection of the society. So the language used on media can also be a more subtle form of prejudice existing in the society. To Maddock (1999) press often defines women as either disadvantaged, dangerous or sinner; and language is use as a tool for this purpose. The stereotypical representation of 'masculinity' and 'femininity' through sensational language is a strong feature of Pakistani media as well. 


\section{Reporting of Crime Cases and the Language Used}

To Carter and Weaver (2003:28) 'gender bias in news reporting is the common notion of the news media across all the societies'. As far as crime reporting is concerned Payvar (2004) refers to rape cases as a source of 'gender typification'. To Zia (1995) such reporting appears as periodic and sensational items. Jewkes (2004) asserts that news about crime reports are designed to shock the readers and through this sensational aspect they try to gain the attention of readers. Referring to the same aspect Devi (2005) asserts that this type of sensational reporting diverts the attention of the readers from the real news. In the case of Pakistan also news papers tend to choose items more yielding to sensationalism. Women in crime reports are described more in terms of their appearance, dressing, age and familial relationships in order to invoke the connotations of weakness and powerlessness. The way Pakistani media covers crime and violence indicates its level of gender bias.

\section{Data for the Research}

Newspapers are used as the main tool to collect data. Headings of crime reports are collected and analyzed from two English newspapers (Dawn and The News), and two Urdu News papers (Jang and Khabrain). The time period of data collection from newspapers is three months i.e. February to April 2007. The data was not collected from the whole newspapers, and only the headings of crime reports in the newspapers were taken that had adjectives used in them. As far as the Urdu newspapers are concerned, mostly the crime news was found either on the page of 'crime edition' or in second, fourth and eight page of the newspaper. While in the English newspapers as crime reports are not limited to a specific page so the data was taken from the different pages of the whole newspaper.

\section{Operational Definition of Crime}

'A crime in a broad sense is an act that violates a political or moral law. In the narrow sense, a crime is a violation of the criminal law. For example, most traffic violations or breach of contracts are not crimes in a legal sense but are a form of violation'. ${ }^{1}$

For the present research the broader sense of crime is taken and the news of rapes, murders, kidnapping, suicide and road accidents are taken as the crime news. The road accidents are generally not counted in the crime reports but as in Pakistani newspapers they are generally reported in the sections/pages specified for the crime reporting, they are included in the present research. Secondly when there is violation of some rule it results in a crime, and in case of road accidents (most of the time) there is violation of some law/rule on the part of drivers or pedestrian that costs someone's life. 


\section{Categorization of Data}

Data is categorized and analyzed to see the differences found in the use of adjectives for gender portrayal in the newspapers. Particular kinds of adjectives are attributed to men and women. The choice of an adjective and its use is based on the received identities for gender in the society. Data has been divided into two categories:

Category A consists of the news in which the particular kinds of adjectives are used for the males.

Category $\mathbf{B}$ consists of the news reports in which the attributed adjectives are used for the females.

\section{Presentation of Data}

The data collected from different newspapers is presented newspaper-wise. Firstly the news taken from Dawn are presented under categories A and B that is followed by the data from The News, and then Jang and Khabrain ${ }^{2}$ respectively.

\section{Presentation of Data from 'Dawn'}

Category A: Under this category there is only one instance of the use of gender specific adjectives found in the newspaper 'Dawn' (see Appendix A).

Category B: This category also has only one example from the newspaper 'Dawn' (see Appendix B).

\section{Presentation of Data from 'The News'}

Category A: As far as 'The News ' is concerned, there is no instance under this category in this newspaper.

Category B: Three headlines were found in 'The News' under this category which represented women in a specific way through attributed adjectives (see Appendix C).

\section{Presentation of Data from 'Jang'}

Category A: In the newspaper 'Jang', under this category no instance is found.

Category B: 'Jang' has only one news headline in this category, in which specific kind of adjective/s are used for women.

\section{Presentation of Data from 'Khabrain'}

Category A: There were three instance found in 'Khabrain' under this category (see Appendix E). 
Category B: Comparatively a greater number i.e. 8 instances were found in 'Khabrain' under this category (see Appendix F).

Thus, the newspaper 'Khabrain' has 11 news headlines in which specific kinds of adjectives are used for men and women: 3 news in which adjectives are used to project men in their role of dominance, power and superiority, and 8 news in which attributed adjectives are used for women to present them as weak, subordinate and submissive.l

\section{Analysis of the Findings}

The newspapers tend to use a particular type of vocabulary for the two genders. The particular types of adjectives are used that show women as powerless; and strength is associated with men through the use of adjectives. If a man is reported as criminal then the inhuman qualities of the agent are put forward in terms of power, for example the following news headline in an Urdu newspaper says:

Mardan: safaak shohar ke katal ke baad bewi aur paanch bache supard-e-khaaq

(The cruel husband kills the wife and five children, the murdered were buried). ${ }^{3}$

In the Pakistani context, the received identities in the general conditions are based on gender stereotypes which are masculine rationality, activity and independence and feminine emotionality, passivity and dependence. Adjectives assigned to the boys $/ \mathrm{men}$ explicitly or implicitly are interesting like active, energetic, wild and angry. On the other hand girls/women are presented as passive, indolent, docile and tamed through certain adjectives such as poor, innocent, effected, depressive, fearful and horrid. Apart from all that, the financial conditions of female victims and male agents are also mentioned with the selective use of adjectives to present women as weak and dependent, while men as powerful and independent.

The study of adjectives used for men and women is significant because they reflect the attributes and qualities that a particular society credits to individuals or groups in terms of gender distinction. These attributes, when reported in the newspapers, project the social approval/ acceptance attached to them. These attitudes about men are credited with the language force when discussed in the newspapers e.g. the male perpetrators are presented in term of their brutality to associate the idea of powerfulness. While in an opposite pattern, beauty, powerlessness, and the idea of the innocence is highlighted to refer a woman in the newspaper reporting of crime cases. Particularly when a woman is the victim of a crime, certain attributive words of powerlessness and innocence are used such as a newspaper headline shows:

'Shohar ki taraf se zinda jalane ki koshish, mazloom aurat adaalat pohanch gae'. 
(Attempt from husband to burn alive, poor woman reached the court.)

This type of language pattern creates as well as reflects the roles and attributes associated to women and men in the social structure.

The adjectives for the female victims are mostly associated to their misfortune as is given in the following news headlines:

'Agonized mother seeks arrest of son's killer'.

'Abandoned woman shifted to crises centre'.

These news show the powerlessness on the part of the female victims. Generally we do not come across any news about a male member of the society in which he has been reported as the victim of fate. In the collected data we do not find any news in which the particular kind of adjectives are used that attribute the idea of powerlessness to male victim.

The subjective coverage is not the only form of downgrading a woman victim but also adjectives and terms used for female are subtly devalued. When a woman is at fault, it is often because she is a woman; when a man is at fault it is more often because he is more powerful, cruel, or/ and ambitious. The collected data shows that the adjectives used for man are, 'enraged', and 'monster'. Thus, even when men are presented with a negative connotation, power is an essential attribute. On the other hand women criminals are described in terms of their beauty. Even if a woman is presented as a perpetrator instead of a victim in a crime case, adjectives describing loveliness and beauty are used, which do not generate the idea of power and authority. For instance a news headline in an Urdu daily emphasizes the beauty of the kidnappers as follows:

'Khoobroo karaedar aurtain, hamsai ladki ko barae bag me aghwa kar ke le gaen'

(Beautiful women kidnapped the neighbourhood girl in the big bag).

It shows the general acceptability on the part of the readers who unconsciously accepts the biased portrayal even at such a level. The above given example shows that for a woman, whether a victim or an agent of crime, her physical aspect can never be ignored in her portrayal because a woman is considered as a commodity and a sex object in the society not as an individual human being.

Another interesting aspect of the choice of adjectives is terms of the social background of the female victim and male agent that is always highlighted in the news headlines. For instance one of the news headlines says:

'Ba-asar obashoon? ki giyara saala ladki se ijtimai ziyadti' 
(Authoritative strays collectively raped 11 years old girl).

This news presents the privileged social status of the male agents and the miserable state of the female victim. Significantly age of the girl is used as an attributive adjective for her which implies weakness, immaturity and powerlessness. This type of reporting depicts the biased attitude of the reporters as well as newspapers towards women.

It is also important to notice that the findings of the data prove that English newspapers comparatively less use gender specific adjectives in the headlines of crime reports. On the whole Urdu newspapers tend to use such adjectives more frequently.

\section{Conclusion}

Media reproduces the conflict between masculinity and femininity and it usually tends to maintain cultural stereotypes of social standards. Newspapers use demeaning and gender specific description/language in portraying the powerless, dependent and disadvantaged image of women in the society. Gender-specific language in newspaper reporting continues in the stories of violence, cases of rape and other crime. This type of coverage of crime creates a stereotyped picture of women in the Pakistani society, and promotes the negative image of women as vulnerable and helpless in certain situations. Docility, weakness and inferiority are additional information that is provided in the news about a female victim through the selective use of adjectives. The attributed adjectives for the victims are associated with some sort of power for men and inability and subjection for women. The findings suggest that both the newspapers, whether English or Urdu, use gender specific descriptions. However, overall Urdu newspapers tend to use gender specific adjectives slightly more frequently. This design of news pattern further reinforces the idea of dependency of women on men, and their subordination to men.

\section{End Notes}

${ }^{1}$ http://en.wikipedia.org/wiki/Crime

${ }^{2}$ All the Urdu words in this research paper are shown in italics.

${ }^{3}$ English translation of Urdu news is given in parenthesis.

\section{References}

Ahmer, T. (2004) Gender and media: Pakistani Perspective. http.//www.southasianmedia.net.

Burki, Z. (2004) Media: Defining roles._Carter, C., \& Weaver, C, k. (2003) Violence and media. Buckingham: The Open University Press. http.//www.chowk.com. 
Cornell, D. (2004) Gender in America In Tazi, N. (Ed.), Keyword gender, Vistaar Publications, New Delhi, India.

Dagar, R. (2004) Gender and media: Indian perspective. http.//www.southasianmedia.net (2007).

Devi, K. U. (2005) Violence against women: Human rights perspective. New Delhi: Serial Publishers.

Frank, E. W., \& Treichler, P. A. (1989) Language, gender and professional writing: Theoretical approaches and guidelines for nonsexist usage. New York: Modern Language Association of America.

Hasan, M. (2001) Mass media in Pakistan. Lahore: Aziz Publishers.

Jasam, S. (2001) Honour, shame \& resistance. Lahore: ASR Publications.

Jewkes, Y. (2004) Media and crime. London: Sage Publications.

Maddock, S. (1999) Challenging women: Gender, culture and organization. New Delhi: Sage Publications.

Manchanda, R. (2004) Gender stereotyping: South Asian Perspective. http.//www.southasianmedia.net

Mayer, B. M., \&Pugh, A. K. (1987) Language, communication and education. London: The Open University Press.

Mohanty, M. (Ed.). (2004) Class, caste and gender. New Delhi \& London \& Thousand Oaks: Sage Publications.

Niranjana, S. (2004) Gender in India In Tazi, N. (Ed.) Keyword gender, Vistaar Publications, New Delhi, India.

Oakely, A. (1972) Sex, gender and society. London: Halper Colophon Books.

Payvar, B. (2004) Newspapers coverage of gender, environment and development Issue in India. http://theses.lub.lu.se/archive/2005/12/28/1135779153-17297-313/PayvarMT.pdf

Tassaro, E. (2002) Stereotypes and ideals: Femininity in the media. http://www.nd.edu/ frswrite/issues/2002-2003/tassaro.shtml 
Warton, A. S. (2005) The sociology of gender. Australia \& USA \& UK: Blackwell Publishing.

Zia, A. S. (2004) Gender and media: Pakistani perspective. http//www.southasianmedia.net

\section{Appendices}

Appendix A: Table 1: Findings of category A, Dawn (English)

Enraged man kills wife, mother in law. 22/4/07

Appendix B: Table 2: Findings of category B, Dawn (English)

Abandoned woman shifted to crises centre. 27/3/07

Appendix C: Table 3: Findings of category B, The News (English)

Agonized mother seeks arrest of son's killer. 11/4/07

Justice urged for 'tortured girl'. 9/ 4/07

Terrified mother finds justice hard to see. 30/4/07

Appendix D: Table 4: Findings of category B, Jang (Urdu)

Faisalabad: Nojawan ne shadi men nakami par nobiahta dulhan par tezaab phenk diya. 18/ $4 / 07$

Appendix E: Table 5: Findings of category A, Khabrain (Urdu)

Mardan: safaak shohar ke katal ke baad bewi aur paanch bache supard-e-khaaq.26/2/70

Ba asar obashoun ki giyara saala ladki se ightimai ziyadti. 26/2/07

Bewa ke plot par ba asar afraad ne qabza kar liya. 4/ 4/07

Appendix F: Table 6: Findings of category B, Khabrain (Urdu)

Sector G12/4 Khoubroo karaedar ourtain, hamsai ladki ko barae bag me aghwa kar ke le gaen. 14/4/07

G 8/4 jawan saala maalka se mulazm ki gun point par ziyadti. 8/ 3/07

Mazloom ladki ke waaldain insaaf ke talib hen (with a picture of a rape victim). 10/4/07

Masoom bachi se ziyadti ke baad qatl ka bahana. 24/4/07

Yusra case me police ki ghaflat, Mazloom taalba ke waldain sadar ko darkhast de chuke hain.

10/4/07

Masqat ki khatoon se Pakistani shohar ne jaidad hathia li, katl ki dhamkian, Mutasra aurat khabrain pohanch gae. 19/3/07

Shohar ki taraf se zinda jalane ki koshish, Mazloom aurat adaalat pohanch gae. 2/ 2/07

Ightimai ziyadti ka shikaar hone wali, Naseema Chohan insaaf ki muntazir, Mazloom ladki abhi tak insaaf ki mutalashi he. 14/2/07

Gujranwala, Hawa ki beti ightimai ziyadti ke baad frokht, muqadma darj karne par dobara aghwa kar liya, Badnaseeb khatoon insaaf keliye darbadar ki thokrain khane par majboor. 1/ $3 / 07$ 
Sarwet Rasul is lecturer in the Department of English, Fatima Jinnah University, Rawalpindi, Pakistan.

Sidra Irshad has graduated in English from Fatima Jinnah Women University. 